\title{
WEB-BASED QUESTIONNAIRES - A TOOL USED IN A CAMPYLOBACTER OUTBREAK INVESTIGATION IN STOCKHOLM, SWEDEN, OCTOBER 2007
}

B de Jong (birgitta.dejong@sll.se) ${ }^{1}$, C Ancker ${ }^{1}$

1. Department of Communicable Disease Control and Prevention, Stockholm County Council, Stockholm, Sweden

Campylobacteriosis is the most common reported bacterial gastrointestinal disease in Sweden. Food-borne outbreaks of campylobacteriosis in Sweden are rather rare except for, usually rather small, family outbreaks. Water-borne outbreaks of campylobacteriosis, however, have affected several thousand persons in the past [1].

In the beginning of November 2007, the regional routine surveillance of campylobacteriosis in Stockholm County detected two cases that were possibly connected with each other. When exploring this possibility, it was revealed the at least 10 people had suffered from diarrhoea after dining from a buffet served to celebrate the anniversary of an organisation. This buffet was served on 10 October 2007. The buffet was served to about 100 persons and had been delivered by a catering company in Stockholm. The name of the company was communicated to the Environment and Health Administration in Stockholm City, which carried out an inspection of the company's kitchen and their routines. As the buffet was suspected as the source of the outbreak, an epidemiological investigation was launched. It was also decided for the first time in Stockholm County to use a web-based questionnaire.

\section{Method}

To investigate the outbreak, a retrospective cohort study was performed among guests of an organisation's anniversary on 10 October 2007, in Stockholm, Sweden. A case was defined as a person who experienced stomach problems following the event. People who had not been eating from the buffet were excluded from the analysis. An electronic web-based questionnaire (Figure 1 ) was sent to people who had given their email addresses, and paper questionnaires to the remaining guests.

\section{Epidemiological investigation}

The contact person in the celebrating organisation provided a list of what had been served on the buffet. A list with contact details for the invited guests was also obtained. Of the 93 people on the list, 58 had given their email address and 35 their postal address.

A questionnaire was developed containing questions about onset of disease, symptoms and food items consumed from the buffet. The questionnaire was designed to be web-based with the help of a commercially available programme [2]. An individual link to the web-based questionnaire was distributed to the 58 guests with an email address, while the rest of the guests received a modified questionnaire through the post with a pre-paid response envelope included. Because an individual link was used, no names or addresses were recorded in the response database.

\section{Results}

Sixty-seven people (72\%) answered the questionnaire. Among those who had received the questionnaire through a personal link, $78 \%(45 / 58)$ responded, while the response rate among those who had received it via ordinary mail was $63 \%(22 / 35)$. The database created by the web programme was updated with the results from the ordinary mail questionnaires.

Ten people had not consumed anything from the buffet and all of them remained healthy. Fifty-seven people had consumed food from the buffet, and 22 of them experienced stomach problems following the event. The day of onset of symptoms for each patient is shown in Figure 2.

Four patients had stool cultures positive for campylobacter and two of them were hospitalised due to a severe infection. It is not known how many people were sampled in connection to this outbreak, since there is no register on negative stool cultures. The median age was 54 years among the affected guests and 52 years among the healthy guests, with no significant difference regarding gender. Diarrhoea dominated among the symptoms, see Figure 3.

The cohort study showed that only one of the food items served on the buffet had a significant relative risk associated with gastrointestinal illness and that was the marinated chicken, see Table.

\section{Discussion}

The cohort study revealed that the marinated chicken was the food item suspected to have harboured the campylobacter bacteria. Raw or under-done chicken is a well-known source of campylobacter infection. Of the 206 reported Swedish food-borne during 2005, nine outbreaks with a total of 38 affected persons were caused by campylobacter, and among the sources stated were chicken and chicken liver [3].

Since the outbreak was detected rather late, we will not be able to clarify fully what had happened during the preparation of the chicken that was served at this event. 
F I G U R E 1

Web-based questionnaire used in a campylobacter outbreak investigation in November 2007 in Stockholm, Sweden

\section{$\Longleftarrow\lfloor$ Stockholms läns landsting \\ Smittskyddsläkaren}

$\begin{array}{ll}1 \text { At du av den buffé som serverades? } & \text { C Ja (Yes) } \\ \begin{array}{l}\text { (Did you consumed anything from the buffet } \\ \text { served?) }\end{array} & \text { C Nej (No) } \\ & \text { C Minns ej (Do not remember) }\end{array}$

\begin{tabular}{|c|c|c|c|}
\hline \multicolumn{4}{|c|}{ Vad át du av frản den buffé som serverades? (What did you consumed from the buffet?) } \\
\hline & $\mathrm{Ja}($ Yes) & $\mathrm{Nej}(\mathrm{No})$ & $\begin{array}{l}\text { Minns ej (Do not } \\
\text { remember) }\end{array}$ \\
\hline Shish kebab & $\Gamma$ & $\Gamma$ & $\Gamma$ \\
\hline Hommous & $\Gamma$ & $\Gamma$ & $\Gamma$ \\
\hline Slata Mechwia (grilled pepper salad) & $\Gamma$ & \ulcorner & $\Gamma$ \\
\hline Oriental salad & $\Gamma$ & $\Gamma$ & $\Gamma$ \\
\hline Falafel & $\Gamma$ & $\Gamma$ & $\Gamma$ \\
\hline Marinated chicken & $\Gamma$ & $\Gamma$ & $\Gamma$ \\
\hline Basmati rice & $\Gamma$ & $\Gamma$ & $\Gamma$ \\
\hline Youghurt sauce & $\Gamma$ & $\Gamma$ & $\Gamma$ \\
\hline Tomato sauce & $\Gamma$ & $\Gamma$ & $\Gamma$ \\
\hline
\end{tabular}

F I G U R E 2

Date of onset of symptoms among people attending an anniversary in Stockholm, Sweden in October $2007(n=19)$

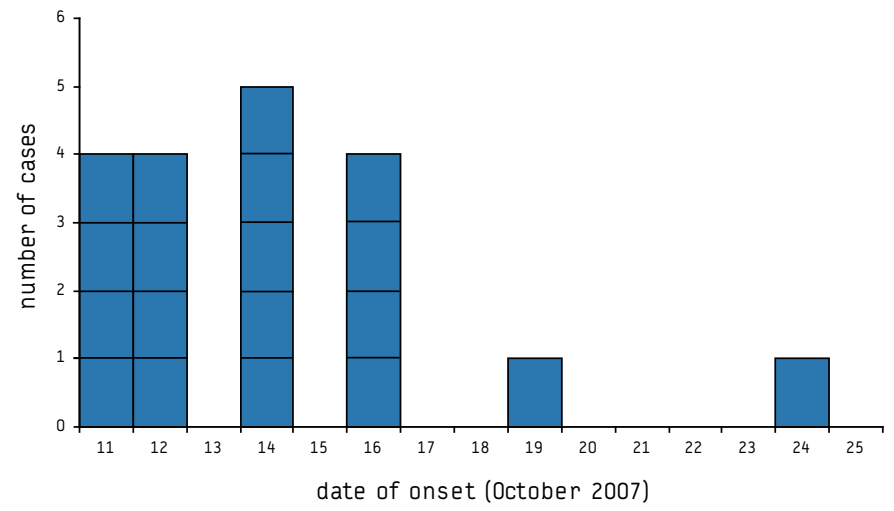

F I G U R E 3

Percentage of cases experiencing different symptoms (several options possible) after an anniversary in Stockholm, Sweden, October $2007(n=19)$

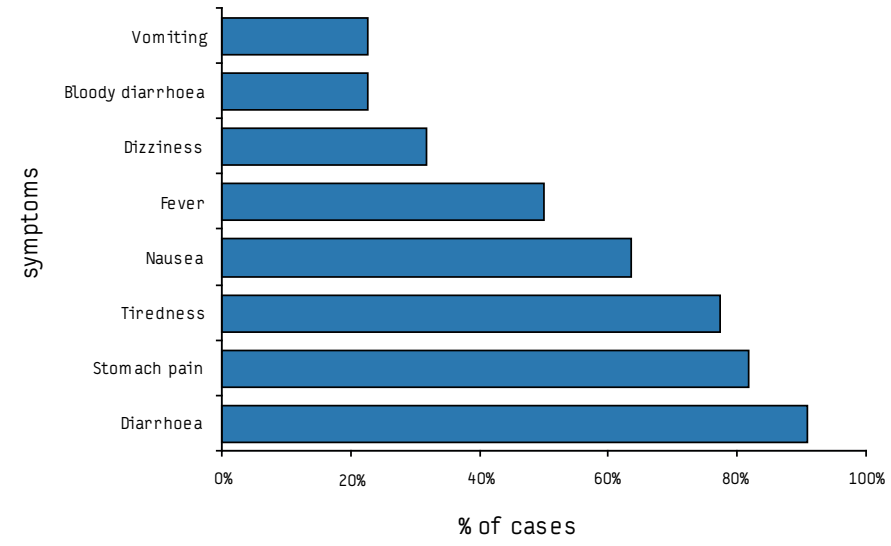

T A B L E 1

Relative risk per food item consumed from a buffet connected to an outbreak of campylobacteriosis in Stockholm, Sweden, October 2007

\begin{tabular}{|l|c|c|}
\hline Food & Relative risk & $\begin{array}{c}95 \% \text { confidence } \\
\text { interval }\end{array}$ \\
\hline Shish kebab & 1,88 & $0,50-7,00$ \\
\hline Hommous & 1,90 & $0,32-11,5$ \\
\hline $\begin{array}{l}\text { Slata Mechwia (grilled } \\
\text { pepper salad) }\end{array}$ & 0,93 & $0,37-2,29$ \\
\hline Oriental salad & 0,63 & $0,26-1,52$ \\
\hline Falafel & 1,84 & $0,30-11,2$ \\
\hline Marinated chicken & 3,88 & $1,01-14,9$ \\
\hline Basmati rice & 0,78 & $0,19-3,24$ \\
\hline Yoghurt sauce & 1,56 & $0,44-5,50$ \\
\hline Tomato sauce & 0,69 & $0,31-1,53$ \\
\hline
\end{tabular}


This outbreak investigation showed how convenient it is to use web-based questionnaires in this kind of investigations. Most advantageous was that data did not have to be entered from a questionnaire form into a database, which saved a lot of time. The programme also created a code book in which every question and the alternative answers were stated. Another advantage over questionnaires sent by ordinary mail was that the response from the people who had received web-based questionnaires was much quicker. A problem with web-based questionnaires at the moment is that the servers on which all the data is stored, belongs to the companies from which the data programmes are hired. If the programme is bought, an extra server is necessary that is not protected by a firewall. This must be considered when thinking of the private data and personal integrity of the people answering the web-based questionnaires. A solution to this problem would be welcome.

\section{References}

1. Swedish Institute for Infectious Diesease Control. Statistik för campylobacterinfektion. Available from: http://www.smittskyddsinstitutet. se/statistik/campylobacterinfektion/

2. Artologik. Query\&Report - Queries and Surveys. Available from: http://www. artologik.com/en/QueryAndReport.aspx

3. R Lindqvist, A Westöö, $M$ Hjertqvist, $Y$ Andersson. [Reported suspected food poisonings 2005]. 12 oktober 2006 [In Swedish]. Available from: http://www. slv.se/upload/ dokument/rapporter/matforgiftning_mathantering/2006_ Rapporterade_Matforgiftningar_2005.pdf

This article was published on 24 April 2008.

Citation style for this article: de Jong B, Ancker C. Web-based questionnaires - a tool used in a campylobacter outbreak investigation in Stockholm, Sweden, October 2007. Euro Surveill. 2008;13(17):pii=18847. Available online: http://www.eurosurveillance.org/ ViewArticle.aspx?ArticleId $=18847$ 